\title{
MODAL SOSIAL DAN KEBERLANJUTAN USAHATANI MENDONG
}

\section{SOCIAL CAPITAL AND SUSTAINABLE OF MENDONG FARM}

\author{
Tenten Tedjaningsih*, Dedi Sufyadi \\ Program Studi Agribisnis Fakultas Pertanian Universitas Siliwangi \\ *Email: tenten ks@yahoo.co.id \\ (Diterima 19-02-2020; Disetujui 25-04-2020)
}

\begin{abstract}
ABSTRAK
Kapasitas petani sebagai pelaku usahatani tidak dapat lepas dari dukungan potensi yang dimilikinya, yang mencakup potensi individu dan potensi kelompok. Potensi individu dapat berupa kekuatan fisik dan intelektual sedangkan potensi kelompok meliputi kemampuan bekerja sama dan kepercayaan. Kemampuan untuk bekerjasama merupakan kemampuan untuk mengesampingkan kepentingan pribadi bagi kepentingan kelompok yang lebih besar sedangkan kepercayaan pada akhirnya akan menghasilkan rasa tanggung jawab dan keduanya tergantung kepada derajat kelompok berbagi norma dan nilai. Kemampuan kelompok ini disebut dengan modal sosial. Metode penelitian yang digunakan adalah survey terhadap petani mendong di Desa Kamulyan Kecamatan Manonjaya Kabupaten Tasikmalaya. Pengambilan sampel secara acak sederhana. Data yang diperoleh dianalisis secara deskriptif serta dianalisis dengan Analisis Koefisien Konkordans Kendall W untuk melihat hubungan antara modal sosial dan keberlanjutan usahanya. Hasil penelitian menunjukan bahwa secara keseluruhan modal sosial yang jaringan kerjasama, resiprocity, kepercayaan, norma/aturan, nilai-nilai kebersamaan, serta proaktif termasuk kategori tinggi. Keberlanjutan usahatani mendong dilihat dari kemampuan petani melaksanakan kegiatan usahatani mendongnya dalam pengadaan sarana produksi, permodalan, pemasaran, berorganisasi kelompok dan memperoleh informasi dan teknologi termasuk cukup baik. Terdapat hubungan yang nyata antar variabel modal sosial dan secara bersama-sama dengan keberlanjutan usahatani mendongnya. Penguatan modal sosial dapat dilakukan seiring dengan penguatan sumberdaya manusia melalui pendidikan, karena pendidikan merupakan sarana berinteraksi dan mengembangkan norma positif yaitu profesionalisme dalam berusahatani mendong
\end{abstract}

Kata kunci: modal sosial, keberlanjutan usahatani mendong, kamulyan

\section{ABSTRACT}

Capacity of farmer can not take away from potencial power themselves, such as individual potencial and group potencial. Individual potencial are such as fisic and intellectual, while group potencial are such as cooperation ability and trust. Cooperation ability is ability to rule out personal make responsibility and both depend on group degree of various norms and values. Ability of group is called by social capital. Method of this research is survei method to the farmer of mendong in Kamulyan Manonjaya Tasikmalaya Regency. Sample responden was taken by simple random sampling. Data was analyzed by descriptive and Konkordans Kendal W analysis to know relationship between social capital and sustainability of business. The result of this research is overall social capital that collaboration network, reciprocity, trust, norm, cooperation value and proactive were included the high category. Sustainability of mendong farming was seen from ability of production facilities, capital, marketing, organize group and obtain information and technology were include as good enough. There was correlation between social capital and sustainability of mendong farm. Power of social capital can be done together by power of human resource through education, because it was means of interacting and developed of positive norms was professionalism of mendong farm.

Keywords: Social capital, sustainability farm of mendong, kamulyan 


\section{PENDAHULUAN}

Keberhasilan pengembangan suatu komoditas tidak hanya dipengaruhi oleh budidaya yang dilakukan oleh petani tetapi juga di luar budidaya, baik pengadaan sarana produksi, penanganan pasca panen, pemasaran maupun jasa penunjang untuk kelancaran kegiatan tersebut, yang membentuk suatu sistem dan disebut dengan agribisnis.

Inti pembangunan yang berpusat pada rakyat menurut Moeljarto Tjokrowinoto dalam Theresia dkk (2014) adalah pemberdayaan (empowerment) yang mengarah pada kemandirian masyarakat. Melalui partisipasi kemampuan masyarakat dan perjuangan mereka untuk membangkitkan dan menopang pertumbuhan kolektif menjadi kuat. Masyarakat dalam pembangunan bukan sebagai objek tetapi ditempatkan sebagai subjek utama yang harus menentukan jalannya pembangunan. Pembangunan berbasis masyarakat berarti pembangunan harus berbasis pada sumberdaya lokal, berbasis pada modal sosial, berbasis pada budaya lokal, menghormati atau berbasis pada kearifan lokal dan berbasis pada modal spiritual yang dimiliki dan atau diyakini oleh masyarakat setempat

Kapasitas petani sebagai pelaku dalam menjalankan kegiatan usahatani- nya tidak dapat lepas dari dukungan potensi yang dimilikinya. Potensi petani mencakup potensi individu dan potensi kelompok. Potensi individu dapat berupa kekuatan fisik dan intelektual yang terdiri atas pengetahuan dan keterampilan yang berasal dari pendidikan, pelatihan dan pengalaman serta lingkungan sehingga mampu menghasilkan inovasi baik dalam usahatani, mengolah hasil pertanian maupun memasarkan produknya

Potensi kelompok juga tidak kalah penting dalam seluruh kegiatan pertanian. Potensi kelompok manusia meliputi kemampuan bekerja sama dan kepercayaan. Kemampuan untuk bekerjasama merupakan kemampuan untuk mengesampingkan kepentingan pribadi bagi kepentingan kelompok yang lebih besar sedangkan kepercayaan pada akhirnya akan menghasilkan rasa tanggung jawab. Keduanya bergantung pada derajat kelompok berbagi norma-norma dan nilai-nilai.

Kehidupan sosial petani mendong dan kondisi ekonomi yang ada menjadi latar belakang yang mendorong peneliti mengkaji lebih jauh tentang keterkaitan hubungan modal sosial dengan keberlan- 
jutan usahatani. Dimana keterkaitan ini bertumpu pada perilaku-perilaku ekonomi petani yang didasarkan oleh perilaku sosial yang ada pada diri petani mendong sehingga hal ini membuat semakin menarik untuk diteliti lebih jauh.

Kapasitas petani baik dari potensi individu maupun kelompok merupakan salah satu asset petani dalam melaksanakan kegiatan usahataninya, pertanian bagi para petani, bukan sekedar sebagai mata pencahariaan, tetapi sudah merupakan cara hidup atau way of life yang membuat sistem nilai, tradisi, dan kepercayaan menjadi pedoman mereka dalam bertindak dan mengambil keputusan. Oleh karena itu, konsep modal sosial sebagai segala sesuatu hal yang berkaitan dengan kerjasama dalam masyarakat untuk mencapai kapasitas hidup yang lebih baik, ditopang oleh nilai dan norma yang menjadi unsur utamanya yaitu kepercayaan, timbal balik dan aturan kolektif masyarakat dianggap dapat memberikan dukungan bagi keberlanjutan usahataninya.

\section{METODE PENELITIAN}

Metode penelitian adalah survei. Jumlah sampel sebanyak 25 orang, diambil secara simple random sampling dari petani mendong yang ada di Desa
Kamulyan Kecamatan Manonjaya. Data yang dianalisis berupa data primer hasil wawancara dengan petani responden. Untuk menguji hubungan secara simultan antara modal sosial dan keberlanjutan usahatani mendong digunakan Analisis Koefisien Konkordans Kendall $W$.

Tabel 1. Pengukuran Variabel Penelitian

\begin{tabular}{|c|c|c|}
\hline $\begin{array}{ll}\text { No } & \text { Variabel }\end{array}$ & Indikator & Skala \\
\hline $\begin{array}{r}\text { Modal } \\
\text { sosial }\end{array}$ & $\begin{array}{l}\text { 1. Partisipasi dalam } \\
\text { jaringan } \\
\text { 2. Reciprocity } \\
\text { 3. Trust/kepercayaan } \\
\text { 4. Norma sosial } \\
\text { 5. Nilai-nilai } \\
\text { 6. Tindakan proaktif }\end{array}$ & Ordinal \\
\hline $\begin{array}{l}\text { 2. Keberlan- } \\
\text { jutan usaha }\end{array}$ & $\begin{array}{l}\text { Kemampuan petani } \\
\text { dalam: } \\
\text { 1. Pengadaan saprodi } \\
\text { 2. Permodalan } \\
\text { 3. Pemasaran } \\
\text { 4. Organisasi petani } \\
\text { 5. Memperoleh } \\
\text { informasi dan } \\
\text { teknologi }\end{array}$ & Ordinal \\
\hline
\end{tabular}

Untuk mengetahui modal sosial yang dimiliki oleh petani serta keberlanjutan usahatani mendong dilakukan secara deskriptif dengan pengkategorian modal sosial: sangat kurang, kurang, cukup, tinggi dan sangat tinggi sedangkan pengkatagorian pada keberlanjutan usahatani adalah sangat kurang, kurang, cukup, baik dan sangat baik. 


\section{HASIL DAN PEMBAHASAN}

Petani yang menjadi responden dalam penelitian ini sebanyak 25 orang yang terdiri atas perempuan $40 \%$ dan laki-laki $60 \%$, responden perempuan ini dalam usahatani mendongnya ada yang mandiri mengelola usahataninya karena warisan dari suaminya tetapi ada juga yang berusaha bersama dengan suaminya.

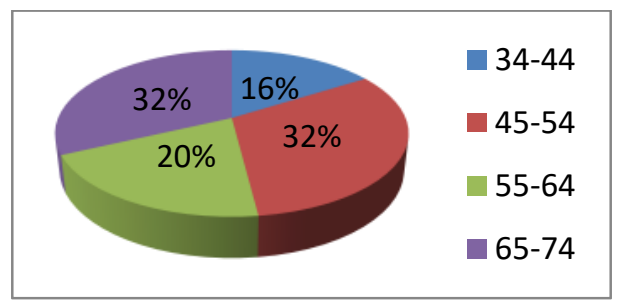

Gambar 1. Umur Responden

Umur responden berkisar antara 3474 tahun, $32 \%$ petani ternyata sudah bukan usia produktif menurut BPS karena berusia di atas 65 tahun (Gambar 1). Selain itu, responden pada umumnya sudah berusahatani mendong lebih dari separuh usianya sehingga usahatani mendong sudah menjadi jalan hidup (Way of life).

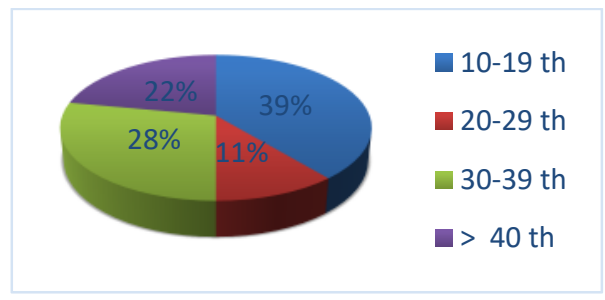

Gambar 2. Pengalaman Usahatani

Tidak ada seorang respondenpun yang hanya berusahatani mendong, pada umumnya juga berusahatani padi sawah selain sebagai buruh, pedagang dan pengrajin mendong. Salah satu penyebabnya adalah karena padi dan mendong merupakan tanaman semusim, sehingga tidak bisa cepat diperoleh hasil dari usahataninya.

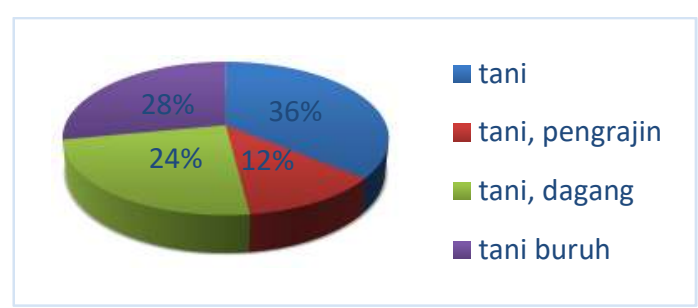

Gambar 3. Pekerjaan Responden

Luas lahan garapan mendong yang diusahakan oleh responden rata-rata kurang dari 0,25 ha, hanya $8 \%$ yang mengusahakan lebih dari 0,5 ha.

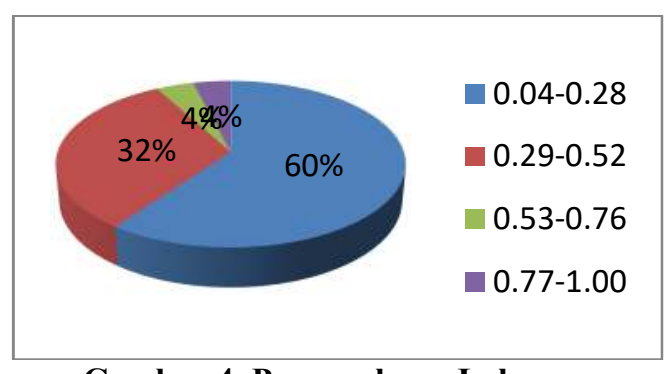

Gambar 4. Pengusahaan Lahan

Status penguasaan lahan pada umumnya $48 \%$ adalah pemilik penggarap selain sebagai penyakap dan sewa.

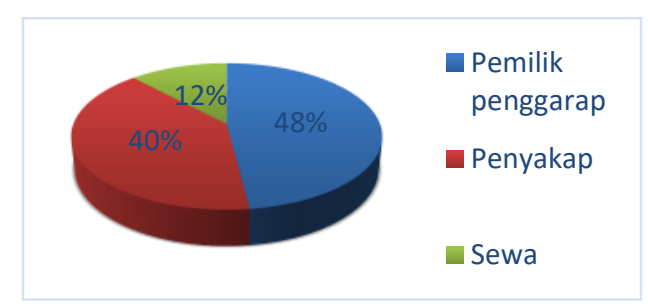

Gambar 5. Penguasaan lahan

\section{Modal Sosial Usahatani Mendong}

Modal sosial merupakan aspek penting untuk membangun pertanian 
yang lebih maju. Dengan modal sosial yang berkembang di lingkungan petani, maka kebersamaan petani menjadi kuat. Wujud dari modal sosial tersebut adalah bahwa petani memiliki kekerabatan kuat dalam meningkatkan daya saing komoditi pertanian yang dihasilkan.

Demikian halnya dengan modal sosial yang dimiliki oleh petani mendong di Desa Kamulyan diharapkan dapat menjadi modal dasar untuk mendorong keberadaan dan keberlajutan usahatani mendong.

Hasil penelitian menunjukan bahwa modal sosial yang dimiliki petani secara keseluruhan termasuk kategori tinggi, seperti terlihat pada Tabel 2.

Tabel 2. Modal Sosial Petani Mendong

\begin{tabular}{lccl}
\hline Modal Sosial & $\begin{array}{c}\text { Skor } \\
\text { maks }\end{array}$ & $\begin{array}{c}\text { Skor } \\
\text { aktual }\end{array}$ & Katagori \\
\hline 1. $\begin{array}{l}\text { Partisipasi dalam } \\
\text { Jaringan }\end{array}$ & 1.375 & 870 & Cukup \\
2. $\begin{array}{l}\text { Reciprosity / Hub } \\
\text { timbal balik }\end{array}$ & 375 & 193 & Kurang \\
3. $\begin{array}{l}\text { Trust } \\
\text { /kepercayaan }\end{array}$ & 750 & 566 & Tinggi \\
4. Norma & 375 & 330 & $\begin{array}{l}\text { Sangat } \\
\text { Tinggi }\end{array}$ \\
5. Nilai-nilai & 500 & 430 & $\begin{array}{l}\text { Sangat } \\
\text { tinggi }\end{array}$ \\
$\begin{array}{l}\text { Kebersamaan } \\
\text { Tindakan proaktif }\end{array}$ & 500 & 390 & Tinggi \\
\hline Total Modal Sosial & 3875 & 2779 & Tinggi \\
\hline
\end{tabular}

Responden dalam modal sosial yang dimilikinya hanya dua orang atau $5 \%$ yang mempunyai modal sosial sangat tinggi, selebihnya ada pada kategori cukup dan tinggi.

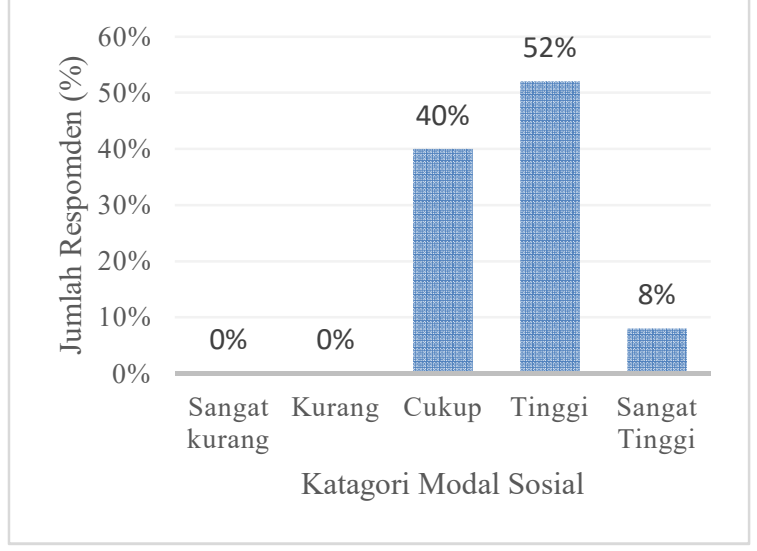

Gambar 6. Sebaran Modal Sosial Petani

Partisipasi dalam suatu jaringan merupakan suatu bentuk partisipasi dari petani dalam kegiatan sosial kemasyarakatan seperti PKK, kelompok tani, keagamaan berupa majelis taklim, pemerintahan seperti RT, RW, dan desa.

Reciprosity adalah kecenderungan saling tukar kebaikan antar individu dalam suatu kelompok atau antar kelompok dapat berupa kepedulian sosial dan kesiapan membantu petani lain atau dalam kegiatan usahatani mendong.

Bentuk kerjasama yang dilakukan dalam usahatani mendong mulai dari pengolahan lahan, pengadaan bibit dan pupuk, panen, penjemuran dan pengadaan modal jarang dilakukan, tidak seperti dalam usahatani padi.

Bantuan tenaga pada kegiatan usahatani mendong pada umumnya jarang dilaksanakan karena pada umumnya kegiatan dilakukan sendiri oleh petani maupun buruh tani. Bantuan 
modal jarang dilakukan karena pada umumnya para petani menggunakan modal usaha sesuai dengan kemampuan yang dimilikinya; demikian juga dengan sarana produksi terutama bibit. Bibit tanaman mendong umumnya berasal dari anakan tanaman sebelumnya sehingga petani tidak perlu membeli bibit setiap musim.

Kepercayaan sangat penting dalam kehidupan bermasyarakat, sama halnya dalam pengembangan usahatani mendong. Kepercayaan dalam penelitian ini adalah kepercayaan petani dalam memperoleh informasi teknologi untuk pengembangan usahatani yaitu percaya terhadap sesama petani dan kelompoknya dalam membuat rancangan kegiatan, kepercayaan terhadap penyuluh pertanian, serta kepercayaan terhadap pasar produk maupun sarana produksi.

Modal kepercayaan yang dimiliki oleh $60 \%$ responden adalah termasuk kategori tinggi. Kepercayaan yang ada di masyarakat tani memungkinkan masyarakat tersebut saling bersatu dan memberikan kontribusi dalam pengembangan usahataninya.

Aturan-aturan dapat berbentuk formal jika masyarakat tersebut bergabung dalam suatu kelompok, akan tetapi dalam kehidupan masyarakat biasanya berupa norma sosial yang sifatnya mengikat ke dalam.

Meskipun para petani tidak bergabung dalam kelompok tani yang formal; tetapi setiap ada kegiatan dalam kelompok tersebut, mereka semaksimal mungkin mengikutinya karena mereka berkeyakinan bahwa melaksanakan program kerja yang telah mereka buat bersama merupakan kewajiban bagi setiap anggotanya agar tujuan program tersebut dapat tercapai. $60 \%$ dari petani termasuk kategori sangat tinggi dan 40\% termasuk tinggi.

Nilai-nilai yang tercermin dalam kehidupan masyarakat tercermin dari perbuatan yang dilakukan sehari-hai yaitu kejujuran dan ketaatan. Nilai-nilai yang ada di masyarakat seharusnya menjadi gagasan yang baik dan penting bagi motor penggerak kelompok seperti adanya rasa kekeluargaan yang terjalin, dan responden menyatakan bahwa kesuksesan kelompok merupakan kesuksesan dari petani itu sendiri.

Masyarakat yang sudah biasa proaktif akan senantiasa melakukan tindakan yang bermanfaat bukan saja bagi dirinya, tetapi juga bagi kehidupan bermasyarakat. Bentuk tindakan proaktif dari para petani adalah bergabungnya mereka dalam kelompok dengan tujuan 
selain untuk bersosialisi, juga untuk menambah ilmu pengetahuan khususnya dalam pengembangan usahatani mendong.

Peningkatan modal sosial melalui kepercayaan, jaringan sosial, tanggung jawab sosial, norma sosial, dan adat istiadat serta unsur kerjasama akan mempengaruhi tingkat pendapatan petani (Harahap dan Herman, 2018).

\section{Keberlanjutan Usahatani Mendong}

Jika dikaitkan dengan sistem agribisnis, kelembagaan adalah termasuk subsistem jasa penunjang, dimana lembaga tersebut harus mampu berperan dalam menunjang terhadap kegiatan dalam subsistem pengadaan sarana produksi, usahatani, pengolahan hasil pertanian dan pemasaran. Petani sebagai pelaku utama adalah subjek dalam pembangunan agribisnis tersebut adalah konsumen dari jasa yang diberikan oleh lembaga penunjang agribisnis tersebut, sehingga agar usahanya berkelanjutan harus mempunyai kemampuan dalam mengaksesnya.

Dukungan kelembagaan sarana produksi, pembiayaan, pemasaran, organisasi petani dan informasi serta teknologi yang memfasilitasi petani dalam melaksanakan usahataninya, serta disertai dengan potensi yang dimilikinya maka akan mempermudahkan petani dalam berkegiatan dan mengembangkan usahatani mendongnya

\begin{tabular}{|c|c|c|c|c|}
\hline No & $\begin{array}{l}\text { Kemampuan } \\
\text { dalam }\end{array}$ & $\begin{array}{l}\text { Skor } \\
\text { maks. }\end{array}$ & $\begin{array}{c}\text { Skor } \\
\text { aktual }\end{array}$ & $\begin{array}{c}\text { Kate- } \\
\text { gori }\end{array}$ \\
\hline 1 & $\begin{array}{l}\text { Pengadaan sarana } \\
\text { produksi }\end{array}$ & 625 & 435 & Baik \\
\hline 2 & Permodalan & 500 & 277 & $\begin{array}{l}\text { Cukup } \\
\text { baik }\end{array}$ \\
\hline 3 & Pemasaran & 500 & 334 & $\begin{array}{l}\text { Cukup } \\
\text { baik }\end{array}$ \\
\hline 4 & Organisasi Petani & 750 & 150 & $\begin{array}{l}\text { Cukup } \\
\text { baik }\end{array}$ \\
\hline 5 & $\begin{array}{l}\text { Memperoleh } \\
\text { informasi dan } \\
\text { teknologi }\end{array}$ & 500 & 335 & $\begin{array}{l}\text { Cukup } \\
\text { baik }\end{array}$ \\
\hline & Total & 2.875 & 1.880 & $\begin{array}{l}\text { Cukup } \\
\text { baik }\end{array}$ \\
\hline
\end{tabular}

Jika dilihat dari sebaran petani dalam keberlajutan usahatani mendongnya, pada umumnya sudah cukup baik, apalagi kemampuan petani dalam pengadaan sarana produksi sudah termasuk kategori baik.

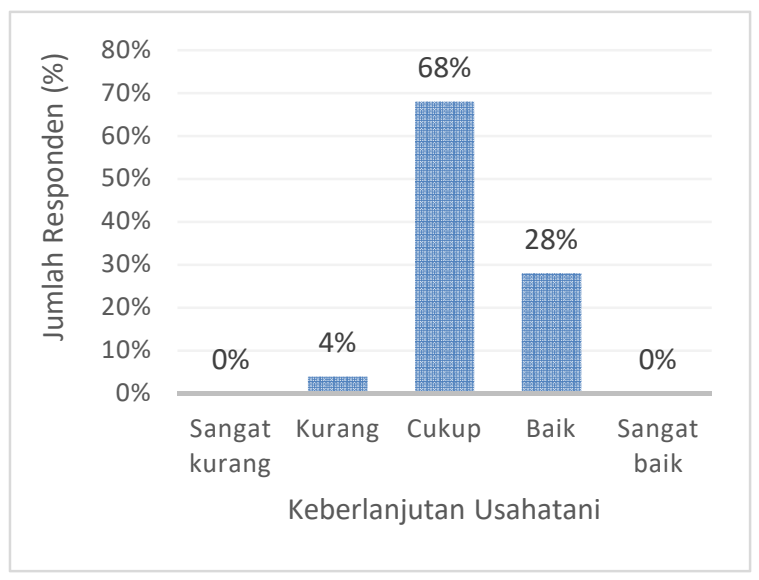

Gambar 5. Sebaran Keberlajutan Usahatani

Keberadaan kios sarana produksi penting bagi bagi petani, dilihat dari kelengkapan, kualitas dan cara pembayaran, dan ketersediaan dari sarana 
produksinya sudah dilaksanakan dengan baik oleh kios sarana produksi sebagai lembaga penyedia sarana produksi, sehingga kinerjanya harus dipertahankan (Tedjaningsih, dkk. 2018).

Kesulitan yang dialami oleh petani dalam pengadaan sarana produksi ini adalah pada saat langkanya sarana produksi sehingga sulit diperoleh dan akhirnya harga menjadi lebih tinggi, artinya petani harus mempunyai modal secara tunai yang lebih besar. Akan tetapi, jika dilihat dari kemampuan petani dalam memperoleh sarana produksi secara keseluruhan termasuk kategori baik.

Keberlanjutan usaha, tidak hanya dilihat dari bagaimana memperoleh sarana produksi pupuk dan bibit serta alat-alat pertanian saja, akan tetapi perlu juga bagaimana kemampuan petani untuk memperluas lahan usahataninya. Upaya untuk memperluas lahan usahatai bisa dengan membeli, sewa ataupun menggadai, dan 37\% responden mampu untuk memperluas lahannya dengan cara tersebut. Luas lahan yang diusahakan kemungkinan berkurang juga dapat terjadi karena lahannya dipakai untuk usahatani padi sawah.

Responden sampai saat ini masih merasa belum membutuhkan pinjaman dari lembaga pembiayaan formal karena petani pada umumnya melaksanakan kegiatan usahataninya sesuai dengan kemampuan keuangannya sehingga dilihat dari kemampuan permodalan termasuk kategori cukup (Tabel 3), meskipun ada $12 \%$ petani yang sangat kurang dalam kemampuan permodalan.

Harga mendong cenderung berfluktuasi, jika permintaan banyak tetapi produk sedikit maka harga cenderung meningkat. Harga juga tergantung kualitas. Berkurangnya produk dan kualitas mendong dapat disebabkan kurangnya permeliharaan seperti pemupukan dan pembersihan, serangan hama, pengairan dan cuaca.

Kemampuan dalam pemasaran hasil produksinya secara keseluruhan termasuk cukup baik (Tabel 3), dan jika dilihat dari sebaran kemampuan responden $16 \%$ sudah termasuk kategori sangat baik dalam pemasarannya.

Keberadaan kelompok tani sebagai penyedia sarana produksi juga dirasakan penting karena selama ini responden membeli bahan kebutuhan produksi usahataninya dari kios produksi di wilayahnya. Responden berharap jika sarana produksi disediakan kelompok maka harganya bisa lebih murah, sehingga ada keuntungan langsung yang 
diterima dari adanya perbedaan harga dengan harga dari kios lain. Secara keseluruhan kemampuan petani dalam organisasi kelompok tani termasuk cukup baik (Tabel 3), meskipun masih ada $4 \%$ responden yang sangat kurang dalam kemampuan berkelompoknya.

Responden berharap perlu ditingkatkan lagi kegiatan pelatihan mengenai inovasi mending, tidak hanya berupa sosialisasi saja. Secara keseluruhan responden cukup baik kemampuannya dalam memperoleh informasi dan teknologi ( Tabel 3) meskipun jika dilihat masih terdapat $4 \%$ responden kurang memiliki kemampuan tersebut.

Hasil analisis dengan menggunakan Analisis Konkordan Kendall W, pada $\alpha=$ 0,01 kerjasama dalam jaringan sosial, reciprosity, kepercayaan, norma/aturan, nilai-nilai kebersamaan dan proaktif secara bersama-sama mempunyai hubungan yang sangat signifikan dengan keberlanjutan usaha terdapat hubungan yang sangat. Tingkat keeratan hubungannya sangat tinggi yang diperlihatkan oleh nilai W Kendall sebesar 0,938 .

Keberlanjutan usahatani mendong yang dilihat dari kemampuan petani tersebut dalam memperoleh sarana produksi, permodalan, pemasaran, berorganisasi serta mengakses informasi dan teknologi sangat berhubungan dengan modal sosial yang dimilikinya, yaitu kerjasama dalam jaringan sosial, reciprosity, kepercayaan, norma/aturan, nilai-nilai kebersamaan dan proaktif yang saling terkait satu dengan yang lainya.

Fukuyama (2010) menyatakan bahwa modal sosial dapat dilembagakan dalam bentuk kelompok sosial. Modal sosial sebagai segala sesuatu yang membuat masyarakat bersekutu untuk mencapai tujuan bersama atas dasar kebersamaan dan di dalamnya diikat oleh nilai dan norma yang tumbuh dan dipatuhi, dan menjadi kunci keberhasilan pembangunan ekonomi dan demokrasi. Krishna (2008) dalam Usman (2018) juga menyatakan dalam level komunitas modal sosial diyakini sebagai asset yang mampu menggerakan beragam komunitas dalam melakukan kegiatan ekonomi.

Kepercayaan dalam konteks bisnis menurut Sako (1992) dalam Damsar dan Indrayani (2018) dapat berbentuk kepercayaan kompetensi, kontraktual dan niat baik. Kepercayaan memperbesar kemampuan manusia untuk bekerjasama, kerjasama tidak mungkin terjalin jika tidak berdasarkan adanya saling percaya diantara yang saling terlibat. Demikian 
halnya antar petani mendong ataupun dengan pedagang dalam memperoleh sarana produksi, permodalan maupun dalam penjualan produk, demikian juga terhadap institusi seperti penyuluh pertanian dan pemerintah yang memberikan informasi teknologi dalam meningkatkan produktivitas usahanya.

Hasil penelitian Anggita (2013) menunjukkan bahwa krisis kepercayaan menjadi pengikis modal sosial dan penghambat utama terwujudnya kolektivitas usahatani.

Reciprocity merupakan pola pertukaran dalam nuansa altruism atau semangat membantu da mementingkan kepentingan orang lain. Pada masyarakat yang didalamnya memiliki bobot resiprositas yang kuat akan melahirkan suatu masyarakat yang memiliki modal sosial yang tinggi, terlihat dari tingkat kepedulian yang tinggi dan saling memperhatikan, sehingga pada masyarakat tersebut akan lebih mudah membangun diri sendiri, kelompok dan lingkungan sosial dan fisik (Alfitri, 2011). Demikian halnya pada masyarakat tani mending, ternyata dari hasil penelitian secara bersamaan dengan modal sosial lainnya mempunyai hubungan yang sangat erat dengan keberlanjutan usahatani.
Norma sosial akan berperan dalam mengontrol perilaku dalam masyarakat dan melembaga dan mengandung sanksi yang dapat mencegah individu menyimpang dari kebiasaan yang berlaku. Demikian juga dalam kehidupan petani mendong dan pemasar dan institusi lainnya dengan adanya norma tersebut maka dapat saling menguatkan meskipun dalam berada dalam persaingan usaha untuk mencapai keuntungan.

Tindakan proaktif yang merupakan modal sosial menyebabkan mereka selalu mencari kesempatan mencari informasi dan inovasi teknologi untuk mengembangkan usaha, baik secara pribadi maupun secara bersama-sama.

Tipe modal sosial yang dimiliki oleh petani dapat bertipe modal sosial yang mengikat karena merupakan ikatan antar kelompok petani yang mempunyai tujuan yang sama untuk keberlajutan usahatani mendong sebagai sumber pendapatan keluarga. Jika dilihat dari pemanfatan modal sosial yang dimiliki oleh petani sehingga mampu untuk meningkatkan daya tawar petani, maka modal sosial yang dimiliknya merupakan tipe modal sosial yang menjembatani. Tipe modal sosial yang menghubungkan juga dapat terdeskripsikan dari adanya jaringan sosial yang terjadi antara petani 
dengan lembaga pemasaran yang akan membeli mendongnya dan menjembatani antara petani dan institusi baik swasta maupun pemerintah yang memberikan informasi dan teknologi.

\section{KESIMPULAN DAN SARAN}

\section{Kesimpulan}

1. Secara keseluruhan modal sosial yang dimiliki oleh petani yaitu partisipasi dalam jaringan, reciprocity, trust, norma, nilai-nilai dan tindakan proaktif termasuk kategori tinggi, dan modal sosial tersebut merupakan modal sosial yang mengikat, menjembatani dan menghubungkan.

2. Keberlanjutan usahatani mendong dilihat dari kemampuan petani dalam pengadaan sarana produksi termasuk baik; sedangkan kemampuan dalam permodalan, pemasaran, organisasi kelompok dan memperoleh informasi dan teknologi termasuk cukup baik.

3. Terdapat hubungan antar variabel modal sosial dan secara bersama-sama mempunyai hubungan yang nyata antara modal sosial yang dimiliki oleh petani dengan keberlanjutan uahatani mendongnya.

\section{Saran}

Keikutsertaan dalam kegiatan dari perkumpulan dan aktif melakukan hubungan social, baik di dalam maupun di luar kelompoknya, dapat mempererat persaudaraan dan pertemanan, yang nantinya dapat mewujudkan kerjasama /kemitraan yang dapat mendukung keberlanjutan usaha.

Penguatan modal sosial dapat dilakukan seiring dengan penguatan sumberdaya manusia melalui pendidikan, karena pendidikan merupakan sarana berinteraksi dan mengembangkan norma positif yaitu profesionalisme dalam berusahatani mending.

\section{DAFTAR PUSTAKA}

Alfitri. (2011). Community Development. Teori dan Aplikasi. Yogyakarta: Pustaka Pelajar.

Anggita, T. (2013). Dukungan Modal Sosial Dalam Kolektivitas Usaha Tani Untuk Mendukung Kinerja Produksi Pertanian Studi Kasus: Kabupaten Karawang dan Subang. Jurnal Perencanaan Wilayah dan Kota, 24(3): 203-216.

Damsar dan Indrayani. (2018). Sosiologi Ekonomi. Jakarta: Prenadamedia Grup.

Fukuyama, F. (2010). Trust. Kebajikan Sosial dan Penciptaan Kemakmuran. Yogyakarta: Penerbit Qalam.

Harahap, M. dan Herman, S. (2018). Hubungan Modal Sosial Dengan Produktivitas Petani Sayur (Studi Kasus Pada Kelompok Tani Barokah Kelurahan Tanah Enam Ratus Kecamatan Medan Marelan). Agrium, 21(2): 157-165. 
Tedjaningsih, T., Suyudi dan Nuryaman, H. (2018). Peran Kelembagaan dalam Pengembangan Agribisnis Mendong. Mimbar Agribisnis, 4(2): 210-216.
Theresia, A., Krisna S.A, Prima, G.P.N. dan Mardikanto, T. (2014). Pembangunan Berbasis Masyarakat. Bandung: Alfabetha.

Usman, S. (2018). Modal Sosial. Yogyakarta: Pustaka Pelajar. 